\title{
Productivity, acylsugar concentrations and resistance to the two-spotted spider mite in genotypes of salad tomatoes
}

\author{
Joicy V. M. Peixoto ${ }^{1}$, Ana L. A. Ribeiro ${ }^{1}$, Gabriel M. Maciel ${ }^{1}$, Camila S. de Oliveira ${ }^{2}$, \\ Rafael R. Finzi ${ }^{1}$ \& Emmerson R. de Moraes ${ }^{3}$
}

\begin{abstract}
${ }^{1}$ Universidade Federal de Uberlândia/Instituto de Ciências Agrárias. Monte Carmelo, MG, Brasil. E-mail: joicyvmpeixoto@yahoo.com.br (Corresponding author) - ORCID: 0000-0001-6761-1306; analuisa.ribeiro@outlook.com - ORCID: 0000-0002-2963-6374; gabrielmaciel@ufu.br - ORCID: 0000-00023004-9134; rafaelfinzi@hotmail.com - ORCID: 0000-0002-0572-3019

${ }^{2}$ Universidade Federal de Uberlândia/Instituto de Ciências Agrárias. Uberlândia, MG, Brasil. E-mail: camilaagroufu@gmail.com - ORCID: 0000-00024251-1461

${ }^{3}$ Instituto Federal Goiano/Departamento de Agronomia. Morrinhos, GO, Brasil. E-mail: emmerson.moraes@ifgoiano.edu.br - ORCID: 0000-00029616-4688
\end{abstract}

\begin{abstract}
The objective of this study was to characterize genotypes of the salad-type tomato with a determinate growth habit and select genotypes resistant to the two-spotted spider mite for higher productivity and fruit quality. The experiment was conducted at the Horticultural Experimental Station ( $18^{\circ} 42^{\prime} 43,19^{\prime \prime} \mathrm{S}$ and $47^{\circ} 29^{\prime} 55,8^{\prime \prime} \mathrm{W}, 873 \mathrm{~m}$ altitude) of the Universidade Federal de Uberlândia (UFU), Monte Carmelo campus, from January to June 2018. The experimental design was in randomized blocks containing 16 treatments [12 populations of the $\mathrm{F}_{3} \mathrm{RC}_{2}$ generation and four controls: two commercial cultivars (Santa Clara and Rio Grande), the recurrent parent (UFU-057) and the wild species Solanum pennellii (LA-716)] with three repetitions. The accessions UFU-057F $\mathrm{RC}_{2} 10 \# 3.6 .1$ and $\mathrm{UFU}-057 \mathrm{~F}_{3} \mathrm{RC} \mathrm{C}_{2} 13 \# 2.1 .2$ have high potential for genetic improvement regarding resistance to the two-spotted spider mite. The genotypes UFU-13\#4.4.1, UFU-7\#4.7.1, UFU-7\#4.3.2, UFU-13\#2.5.2 and UFU-13\#2.1.3 present higher acylsugar concentrations than $S$. pennellii, in addition to higher productivity and number of fruits per plant. It is suggested to explore combinations between those genotypes previously described with UFU-8\#2.4.1 to obtain hybrids with high acylsugar concentrations, two-spotted spider mite resistance, high productivity and increased fruit mass.
\end{abstract}

Key words: Solanum lycopersicum L., Tetranychus urticae, biotic stress, allelochemicals

\section{Produtividade, teor de acilaçúcares e resistência ao ácaro rajado de genótipos de tomateiro tipo salada}

\begin{abstract}
RESUMO: Objetivou-se com este estudo caracterizar genótipos de tomateiro do tipo salada com hábito de crescimento determinado, selecionar genótipos resistentes ao ácaro rajado, de maior produtividade e qualidade de frutos. O experimento foi conduzido na Estação Experimental de Hortaliças ( $18^{\circ} 42^{\prime} 43,19^{\prime \prime}$ S e 470 29' 55,8" $\mathrm{O}, 873 \mathrm{~m}$ de altitude) da Universidade Federal de Uberlândia (UFU), campus Monte Carmelo, de janeiro a junho de 2018. O delineamento experimental foi em blocos casualizados, contendo 16 tratamentos [12 populaçóes da geração $\mathrm{F}_{3} \mathrm{RC}_{2}$ e quatro testemunhas: duas cultivares comerciais ( Santa Clara e Rio Grande), o genitor recorrente (UFU-057) e a espécie silvestre Solanum pennellii (LA-716)] com três repetições. Os acessos UFU-057F $\mathrm{RC}_{2}$ 10\#3.6.1 e UFU-057 $\mathrm{F}_{3} \mathrm{RC}_{2} 13 \# 2.1 .2$ possuem alto potencial para o melhoramento genético visando resistência ao ácaro rajado. Os genótipos UFU-13\#4.4.1; UFU-7\#4.7.1; UFU-7\#4.3.2, UFU-13\#2.5.2 e UFU-13\#2.1.3 apresentaram teor de acilaçúcares superior ao $S$. pennellii, a maior produtividade e número de frutos por planta. Sugere-se a combinação entre os genótipos anteriormente descritos com UFU-8\#2.4.1 para obtenção de híbridos com alto teor de acilaçúcares, resistência ao ácaro rajado, alta produtividade e incremento na massa de fruto.
\end{abstract}

Palavras-chave: Solanum lycopersicum L., Tetranychus urticae, estresse biótico, aleloquímicos 


\section{INTRODUCTION}

The two-spotted spider mite (Tetranychus urticae) is a pest that causes significant losses in productivity and quality of tomato fruits (Maciel et al., 2018a,b). The main method of controlling the arachnid is chemicals. The indiscriminate use of these products can lead to the development of resistance by the pest and contamination of the environment and fruits (Alyokhin et al., 2015). Improvements in plant resistance to arthropods are essential in the integrated management of the two-spotted spider mite. The introgression of genes that promote antibiosis and antixenosis resistance in tomato plants can be performed by crossing with wild genotypes rich in allelochemicals such as acylsugars (Maluf et al., 2010; Lucini et al., 2015; Gruber, 2017; Maciel et al., 2018a,b).

There are few reports of research aimed at obtaining plants with resistance to the two-spotted spider mite in tomato with a determinate growth habit (self-pruning gene) that have a series of phytotechnical advantages as it is not necessary to perform several costly practices, such as: sprouting, harvesting and training systems; as occur in the cultivation of indeterminate cultivars (Maciel et al., 2018a), which can generate significant reductions in production costs and reductions of manpower and mechanization.

Thus, the objective of this study was to evaluate genotypes of the salad-type tomato with the determinate growth habit as well as the selection of genotypes resistant to the two-spotted spider mite and with characteristics of higher productivity and fruit quality.

\section{Material ANd Methods}

The experiment was conducted at the Horticultural Experimental Station $\left(18^{\circ} 42^{\prime} 43,19^{\prime \prime} S\right.$ and $47^{\circ} 29^{\prime} 55,8^{\prime \prime} \mathrm{W}$, 873 m altitude) of the Universidade Federal de Uberlândia (UFU), Monte Carmelo campus, from January to June 2018. The experimental design was in randomized blocks each containing 16 treatments and three repetitions, totalling 48 plots. The 16 treatments consisted of 12 genotypes of the $\mathrm{F}_{3} \mathrm{RC}_{2}$ generation and four controls which consisted of two commercial cultivars (e.g., Santa Clara and Rio Grande), a recurrent parent (UFU-057) and the wild species Solanum pennellii (LA-716). The $\mathrm{F}_{3} \mathrm{RC}_{2}$ population originated from the interspecific cross between Solanum pennellii (LA-716) and $S$. lycopersicum L. (UFU-057), followed by two self-fertilizations and two backcrosses. Each plot consisted of four plants (one plant per pot) and totalled 192 plants.

The 12 genotypes belonging to the $\mathrm{F}_{3} \mathrm{RC}_{2}$ generation were derived from the $\mathrm{F}_{2} \mathrm{RC}_{2}$ selection. The choice was made by prioritizing the plants with the highest concentrations of acylsugar after establishing a truncation point considering values above $70 \%$ of the acylsugar concentrations found in leaflets of Solanum pennellii. To obtain the $\mathrm{F}_{3} \mathrm{RC}_{2}$ generation, mature fruits were harvested and seeds $\left(\mathrm{F}_{3} \mathrm{RC}_{2}\right)$ were extracted from the 12 previously selected plants $\left(\mathrm{F}_{2} \mathrm{RC}_{2}\right)$. The 12 genotypes of the $\mathrm{F}_{3} \mathrm{RC}_{2}$ generation along with the wild access Solanum pennellii, cv. Santa Clara, cv. Rio Grande and UFU057 were seeded in polystyrene trays with 200 cells and filled with commercial substrate based on coconut fibre. Seeding was carried out on January 2, 2018. Thirty-eight days after sowing (02/09/2018), the seedlings were transplanted to $5 \mathrm{~L}$ pots which contained a substrate which consisted of a mixture with a 1:1 ratio of soil and commercial substrate based on coconut fibre. The plants were cultivated in an arc-type greenhouse with dimensions of $7 \mathrm{~m} \mathrm{x} 21 \mathrm{~m}$ and a right foot of $4 \mathrm{~m}$ and were covered with 150 micron transparent polyethylene film, which was added for ultraviolet ray protection and anti-aphid white screen side curtains. Irrigation and cultural treatments were performed in the experiment as recommended by Alvarenga (2013).

The properties analysed were as follows:

Acylsugar concentrations in leaflets: these levels were quantified 30 days after transplanting the seedlings by sampling six leaf discs (equivalent to $4.2 \mathrm{~cm}^{2}$ ) located in the upper third of each plant in a plot. Determinations of acylsugar concentrations were performed according to the methodology proposed by Resende et al. (2002) and adapted by Maciel \& Silva (2014). Two measurements per plant were conducted and the acylsugar concentrations were estimated by taking the mean of both measurements.

Relative superiority: this provides an indication of how much higher the acylsugar amounts in the genotypes studied are compared to $S$. pennellii. The following formula was used in the calculations:

$$
\% \text { relative }=\left[\left(\frac{\mathrm{C} 1}{\mathrm{C} 2}\right)-1\right] 100
$$

in which:

\%relative - equivalent to the difference in percentage of $\mathrm{F}_{3} \mathrm{RC}_{2}$ genotypes in relation to the wild parent LA-716;

$\mathrm{C} 1$ - corresponds to the concentrations of acylsugars in the leaflets of the $\mathrm{F}_{3} \mathrm{RC}_{2}$ genotypes $\left(\mathrm{nmol} \mathrm{cm}^{-2}\right)$; and

$\mathrm{C} 2$ - equivalent to the concentrations of acylsugar in the leaflets of the LA-716 parent ( $\mathrm{nmol} \mathrm{cm}{ }^{-2}$ leaf area).

Resistance to Tetranychus urticae was determined according to the repellency test proposed by Weston \& Snyder (1990). The distance travelled by the mite in the tomato leaflet was measured with a ruler at times of 5, 10, 15 and $20 \mathrm{~min}$. The readings started after a mite was placed on a thumbtack that was attached to the centre of the tomato leaflet. The two-spotted spider mite was already present in the environment where the experiment was conducted because another test had previously been carried out using the same pest.

Productivity (kg per plant) was quantified by weighing the fruits on a scale. The number of fruits per plant was determined by counting the fruits. The average mass of a fruit (FM) was obtained by dividing the value of the productivity by the number of fruits per plant.

Determination of soluble solids (SS) concentrations was performed on 10 fruits per plant. The measurements were carried out using four drops of pulp from each fruit by means of a portable refractometer, model RT-30ATC.

Titratable total acidity (TTA), the ratio between soluble solids concentration and titratable total acidity (SS/TTA), 
acidity in citric acid (ACA) and $\mathrm{pH}$ were quantified according to AOAC (2016).

The glandular trichomes (types I, IV, VI and VII) on the adaxial and abaxial surfaces were counted at 75 and 80 days after sowing and the average between both evaluations was recorded. The evaluations were performed on young and expanded leaflets of tomato by using a stereoscopic microscope (40X) with a micrometric scale of $1 \mathrm{~cm}^{2}$. Five leaflets per plant were evaluated and totalled 20 samples per plot.

The data were subjected to analysis of variance (ANOVA) tests of normality of the residues (Kolmogorov-Smirnov), homogeneity of variances (Levene) and block additivity (Tukey's non-additive test). These tests were performed using IBM SPSS version 25.0.0.0 (IBM SPSS, 2019). Subsequently, ANOVA was performed and the means comparisons were performed by applying the Scott-Knott test at $\mathrm{p} \leq 0.05$. The FM data were transformed by the $\sqrt{ } \mathrm{x}$ function. TTA and ACA, whose values were expressed as percentages, were transformed by the $\arcsin \sqrt{ } \mathrm{x} / 100$ function.

The data were also submitted to multivariate analysis with a goal of characterizing the genetic diversity among the genotypes. A matrix of dissimilarity was obtained by the distance of Mahalanobis, which is the genetic divergence represented by the dendrogram obtained by the hierarchical method Unweighted Pair-Group Method Using Arithmetic Averages (UPGMA), and by Tocher's optimization method. The UPGMA grouping was validated by the co-phenotype correlation coefficient (CCC) as calculated by the Mantel (1967) test.

The relative contributions of the evaluated characteristics were calculated according to Singh (1981). The graphic dispersion was obtained through the analysis of canonical variables. All statistical analyses were performed using the GENES software (Cruz, 2013).

\section{Results ANd Discussion}

Approximately $63 \%$ of the analysed genotypes were superior to $S$. pennellii in their acylsugar concentrations, including UFU-057F $\mathrm{RC}_{2}$ 10\#3.6.1, UFU-057F $\mathrm{RC}_{2}$ 7\#4.3.2, $\mathrm{UFU}-057 \mathrm{~F}_{3} \mathrm{RC}_{2} 8 \# 2.4 .1$, UFU-0 $57 \mathrm{~F}_{3} \mathrm{RC}_{2} 13 \# 4.4 .1$, UFU-057F $\mathrm{RC}_{2} 7 \# 4.7 .1$, UFU-057 $\mathrm{F}_{3} \mathrm{RC}_{2} 7 \# 4.3 .2$, UFU$057 \mathrm{~F}_{3} \mathrm{RC}_{2} 13 \# 2.1 .1$, UFU-0 57F $\mathrm{RC}_{2} 13 \# 2.5 .2$, UFU $057 \mathrm{~F}_{3} \mathrm{RC}_{2} 13 \# 2.5 .1$ and UFU-057F $\mathrm{RC}_{2} 13 \# 2.1 .3$ (Table 1 ). Accesses UFU-057F $\mathrm{RC}_{2} 7 \# 4.7 .3$ and UFU-057F $\mathrm{RC}_{2} 13 \# 2.1 .2$ were similar to $S$. pennellii in their acylsugar concentrations. Increases in acylsugar concentrations were observed in the results of relative superiority in which $75 \%$ of the genotypes were superior to the wild access genotypes UFU-057 $\mathrm{F}_{3} \mathrm{RC}_{2} 13 \# 4.4 .1$, UFU-057F $\mathrm{RC}_{2} 13 \# 2.5 .1$ and UFU-057F $\mathrm{RC}_{2} 10 \# 3.6 .1$ exhibited the highest values for relative superiority, namely, 54.82, 54.51 and $33.42 \%$, respectively, compared to S. pennellii.

The $\mathrm{F}_{3} \mathrm{RC}_{2}$ population expressed transgressive segregation. This consists of the formation of new gene combinations in which the balance present in the parental genotypes is broken by recombination. This promotes the emergence, in segregating generations, of individuals with superior or inferior performance compared to their parents (Resende, 2015). In this work, $63.5 \%$ of the analysed genotypes presented superior performance to $S$. pennellii in terms of their acylsugar concentrations.

Acylsugars can be directly toxic to the two-spotted spider mite (Luu et al., 2017) and can promote its death by immobilizing this insect in the leaves due to its sticky nature

Table 1. Mean concentrations of acylsugar, glandular trichomes and agronomic characteristics of tomato genotypes of the salad type

\begin{tabular}{|c|c|c|c|c|c|c|c|c|c|c|c|c|}
\hline \multirow[t]{2}{*}{ Genotype ${ }^{a}$} & \multirow{2}{*}{$\begin{array}{c}\text { CA } \\
\left(\mathrm{nmols} \mathrm{cm}^{-2}\right)\end{array}$} & \multirow{2}{*}{$\begin{array}{l}\text { RS (\%) to } \\
\text { LA-716 }\end{array}$} & \multicolumn{2}{|c|}{$\begin{array}{c}\text { GT (I, IV, VI and VII) } \\
\text { (nmol cm-2) }\end{array}$} & \multirow{2}{*}{$\begin{array}{l}\text { Prod } \\
\text { (kg) }\end{array}$} & \multirow[t]{2}{*}{ NFP } & \multirow{2}{*}{$\begin{array}{l}\text { FM } \\
(\mathbf{g})^{b}\end{array}$} & \multirow{2}{*}{$\begin{array}{c}\text { SS } \\
\text { ('Brix) }\end{array}$} & \multirow{2}{*}{$\begin{array}{l}\text { TTA } \\
(\%)^{6}\end{array}$} & \multirow[t]{2}{*}{ SS/TTA } & \multirow[t]{2}{*}{$\mathrm{pH}$} & \multirow{2}{*}{$\begin{array}{l}\text { ACA } \\
(\%)^{6}\end{array}$} \\
\hline & & & Adaxial & Abaxial & & & & & & & & \\
\hline 1 & $39.33 \mathrm{~b}$ & 33.42 & $1.58 \mathrm{~d}$ & $1.13 b$ & $0.26 \mathrm{~b}$ & $8.81 \mathrm{~b}$ & $29.90 \mathrm{e}$ & $4.86 \mathrm{e}$ & $0.76 \mathrm{~b}$ & $6.39 \mathrm{a}$ & $4.06 \mathrm{a}$ & $0.49 b$ \\
\hline 2 & $33.00 \mathrm{C}$ & 12.20 & $9.79 b$ & $4.83 \mathrm{~b}$ & $0.29 \mathrm{~b}$ & $12.00 \mathrm{~b}$ & $25.30 \mathrm{e}$ & $6.73 \mathrm{~b}$ & $0.87 \mathrm{~b}$ & $7.77 \mathrm{a}$ & $4.18 \mathrm{a}$ & $0.56 \mathrm{~b}$ \\
\hline 3 & $30.67 d$ & 3.54 & $2.08 \mathrm{~d}$ & $1.50 \mathrm{~b}$ & $0.15 b$ & $7.00 \mathrm{~b}$ & $20.59 \mathrm{e}$ & $6.01 \mathrm{C}$ & $0.84 \mathrm{~b}$ & $7.29 a$ & $4.10 \mathrm{a}$ & $0.54 \mathrm{~b}$ \\
\hline 4 & $33.33 \mathrm{c}$ & 13.76 & $1.50 \mathrm{~d}$ & $1.29 b$ & $0.65 \mathrm{a}$ & $8.17 b$ & $81.86 \mathrm{a}$ & $4.66 \mathrm{e}$ & $0.74 \mathrm{~b}$ & $6.37 \mathrm{a}$ & $4.18 \mathrm{a}$ & $0.47 b$ \\
\hline 5 & $45.67 \mathrm{a}$ & 54.82 & $3.38 d$ & $0.83 b$ & $0.50 \mathrm{a}$ & $13.25 \mathrm{a}$ & $39.63 d$ & $5.61 \mathrm{~d}$ & $0.84 \mathrm{~b}$ & $6.72 \mathrm{a}$ & $4.09 a$ & $0.53 b$ \\
\hline 6 & $36.33 \mathrm{c}$ & 23.05 & $1.00 \mathrm{~d}$ & $2.04 \mathrm{~b}$ & $0.50 \mathrm{a}$ & $22.00 \mathrm{a}$ & $22.47 \mathrm{e}$ & $5.58 d$ & $0.73 b$ & $7.85 \mathrm{a}$ & $4.01 \mathrm{a}$ & $0.47 b$ \\
\hline 7 & $41.00 \mathrm{~b}$ & 38.97 & $4.29 \mathrm{~d}$ & $4.33 \mathrm{~b}$ & $0.52 \mathrm{a}$ & $15.08 \mathrm{a}$ & $34.54 \mathrm{~d}$ & $6.25 \mathrm{C}$ & $0.99 \mathrm{a}$ & $6.40 \mathrm{a}$ & $4.03 \mathrm{a}$ & $0.63 a$ \\
\hline 8 & $33.33 \mathrm{C}$ & 13.58 & $2.58 \mathrm{~d}$ & $1.63 b$ & $0.32 b$ & $6.17 \mathrm{~b}$ & $50.54 \mathrm{C}$ & $5.33 d$ & $0.67 \mathrm{~b}$ & $8.08 \mathrm{a}$ & $4.31 b$ & $0.43 b$ \\
\hline 9 & $38.00 \mathrm{~b}$ & 28.86 & $1.75 \mathrm{~d}$ & $1.96 \mathrm{~b}$ & $0.76 \mathrm{a}$ & $12.92 \mathrm{a}$ & $59.14 b$ & $5.56 \mathrm{~d}$ & $0.86 \mathrm{~b}$ & $6.65 \mathrm{a}$ & $4.09 a$ & $0.55 \mathrm{~b}$ \\
\hline 10 & $45.67 \mathrm{a}$ & 54.51 & $6.75 \mathrm{c}$ & $3.50 \mathrm{~b}$ & $0.49 a$ & $11.08 \mathrm{~b}$ & $44.41 \mathrm{c}$ & $5.94 \mathrm{C}$ & $0.81 \mathrm{~b}$ & $7.50 \mathrm{a}$ & $4.11 \mathrm{a}$ & $0.52 \mathrm{~b}$ \\
\hline 11 & $30.67 \mathrm{~d}$ & 3.46 & $0.88 \mathrm{~d}$ & $0.42 \mathrm{~b}$ & $0.68 \mathrm{a}$ & $18.44 \mathrm{a}$ & $37.03 d$ & $6.05 \mathrm{c}$ & $0.73 b$ & $8.35 \mathrm{a}$ & $4.35 \mathrm{~b}$ & $0.47 \mathrm{~b}$ \\
\hline 12 & $32.33 \mathrm{C}$ & 9.64 & $0.71 \mathrm{~d}$ & $1.04 \mathrm{~b}$ & $0.62 \mathrm{a}$ & $14.25 \mathrm{a}$ & $45.12 \mathrm{C}$ & $5.21 \mathrm{~d}$ & $0.62 b$ & $8.98 \mathrm{a}$ & $4.35 \mathrm{~b}$ & $0.40 \mathrm{~b}$ \\
\hline 13 & $21.67 \mathrm{e}$ & -26.67 & $1.17 \mathrm{~d}$ & $1.67 \mathrm{~b}$ & $0.64 \mathrm{a}$ & $9.83 b$ & $65.63 \mathrm{~b}$ & $4.89 \mathrm{e}$ & $0.78 \mathrm{~b}$ & $6.29 \mathrm{a}$ & $4.14 \mathrm{a}$ & $0.50 \mathrm{~b}$ \\
\hline 14 & $11.66 \mathrm{f}$ & -61.33 & $2.13 \mathrm{~d}$ & $2.63 \mathrm{~b}$ & $0.85 \mathrm{a}$ & $16.58 \mathrm{a}$ & $50.31 \mathrm{c}$ & $5.46 \mathrm{~d}$ & $0.67 \mathrm{~b}$ & $8.21 \mathrm{a}$ & $4.19 a$ & $0.43 \mathrm{~b}$ \\
\hline 15 & $24.33 \mathrm{e}$ & -16.81 & $0.88 \mathrm{~d}$ & $1.38 \mathrm{~b}$ & $0.73 \mathrm{a}$ & $15.36 \mathrm{a}$ & $46.84 \mathrm{c}$ & $5.10 \mathrm{e}$ & $0.73 b$ & $7.03 \mathrm{a}$ & $4.23 \mathrm{~b}$ & $0.46 \mathrm{~b}$ \\
\hline 16 & $29.67 \mathrm{~d}$ & - & $33.42 \mathrm{a}$ & $29.42 \mathrm{a}$ & $0.01 \mathrm{~b}$ & $8.83 \mathrm{~b}$ & $1.35 f$ & $7.57 \mathrm{a}$ & $1.31 \mathrm{a}$ & $6.47 \mathrm{a}$ & $4.09 \mathrm{a}$ & $0.84 \mathrm{a}$ \\
\hline Ks & 0.20 & & 0.20 & 0.01 & 0.20 & 0.20 & 0.20 & 0.20 & 0.20 & 0.20 & 0.16 & 0.20 \\
\hline $\mathrm{F}$ & 0.03 & & 0.001 & 0.00 & 0.06 & 0.10 & 0.09 & 0.12 & 0.01 & 0.04 & 0.00 & 0.01 \\
\hline $\mathrm{F}^{\prime}$ & 0.19 & & 0.03 & 0.29 & 0.88 & 0.87 & 0.01 & 0.11 & 0.23 & 0.70 & 0.07 & 0.23 \\
\hline
\end{tabular}

${ }^{a}$ Means followed by the same letters in a column do not differ by the Scott-Knott test at $\mathrm{p} \leq 0.05 \mathrm{y}$; Ks, F, F' - Assumptions of the Kolmogorov-Smirnov, Levene and Block Additive tests; values in bold indicate residues without normal distributions, homogeneous variances and additive effects. ${ }^{b}$ Data transformed by function $V_{\mathrm{x}}$; ${ }^{\mathrm{C}} \mathrm{Data}$ transformed by the arcsine $\sqrt{\mathrm{x}} / 100$ function; CA - Concentration of acylsugar; SR - Relative superiority (\%) relative to the acylsugar content present in LA-716; GT - Glandular trichomes of type I, IV, VI and VII; Prod - Productivity of fruits per plant; NFP - Number of fruits per plant; FM - Fruit mass; SS - Soluble solids concentration; TTA - Titratable total acidity; SS/TTA - ratio between the soluble solids concentration and the titratable total acidity; ACA - Acidity in citric acid. 1 - UFU-057F $\mathrm{RC}_{2} 10 \# 3.6 .1,2$ - UFU-057F $\mathrm{RC}_{2}$ 7\#4.3.2, 3 - UFU-057F $\mathrm{RC}_{2}$ 7\#4.7.3, 4 - UFU-057F $\mathrm{RC}_{2} 8 \# 2.4 .1,5$ - UFU-057F $\mathrm{RC}_{2} 13 \# 4.4 .1,6$ - UFU-057F $\mathrm{RC}_{2} 7 \# 4.7 .1,7$ - UFU-057F $\mathrm{RC}_{2} 7 \# 4.3 .2,8$ - UFU-057F $\mathrm{RC}_{2} 13 \# 2.1 .1,9$ - UFU-057F $\mathrm{RC}_{2} 13 \# 2.5 .2,10$ - UFU$057 \mathrm{~F}_{3} \mathrm{RC}_{2} 13 \# 2.5 .1,11$ - UFU-057 $\mathrm{F}_{3} \mathrm{RC}_{2} 13 \# 2.1 .2,12$ - UFU-057 $\mathrm{F}_{3} \mathrm{RC}_{2} 13 \# 2.1 .3,13$ - UFU-057, 14 - Santa Clara, 15 - Rio Grande, and 16 - Solanum pennellii 
(Rakha et al., 2017). Several types of acylsugars are produced by tomato. These may exert different effects on various insect species. In addition, other substances are also produced by the glandular trichomes that are capable of promoting plant resistance to insects (Vosman et al., 2018).

The pre-commercial strain UFU-057 presented a negative value for relative superiority $(-26.67)$ when compared to S. pennellii wild access (Table 1). This result is in agreement with several studies (Maluf et al., 2010; Maciel et al., 2018a) and shows the potential of $S$. pennellii as a donor of plant resistance alleles to arthropods due to their high acylsugar concentrations in comparison to pre-commercial cultivars.

The wild access $S$. pennellii presented the highest numbers of glandular trichomes on both the adaxial and abaxial sides of the tomato leaf (Table 1). The S. pennellii access was superior in approximately $93.63 \%$ to the cv. Santa Clara, $96.50 \%$ to the recurrent parent UFU-050 and $97.37 \%$ to the $\mathrm{cv}$. Rio Grande in the quantity of trichomes per $\mathrm{cm}^{2}$ present on the adaxial side of the tomato leaf. The wild access maintained this behaviour with respect to the number of trichomes per $\mathrm{cm}^{2}$ present in the abaxial face of the tomato leaf and presented the greatest amount with values of $91.06,94.32$ and $95.31 \%$, compared to cv. Santa Clara, line UFU-057 and cv. Rio Grande, respectively. These results are in accordance with other studies (Glas et al., 2012) which observed lower trichome numbers in cultivated tomatoes and a marked presence in wild accesses (Rakha et al., 2017; Maciel et al., 2018a; Peixoto et al., 2019).

Genotypes UFU-057F $\mathrm{RC}_{2} 7 \# 4.3 .2$ and UFU$057 \mathrm{~F}_{3} \mathrm{RC}_{2} 13 \# 2.5 .1$ showed intermediate numbers of glandular trichomes on the adaxial side of the leaf (Table 1). These two accessions had higher sugar concentrations than $S$. pennellii (29.67 $\mathrm{nmol} \mathrm{cm}$-2 leaf area) of 33.00 and $45.67 \mathrm{nmol} \mathrm{cm}$, respectively (Table 1 ). Both accesses showed intermediate resistance to the two-spotted spider mite (Table 2).

Table 2. Distances $(\mathrm{cm})$ travelled by Tetranychus urticae at times of 5,10, 15 and $20 \mathrm{~min}$ in various tomato genotypes

\begin{tabular}{|c|c|c|c|c|c|}
\hline \multirow{2}{*}{ Genotypes } & \multicolumn{4}{|c|}{ Time (min) } & \multirow{2}{*}{$\begin{array}{l}\text { Overall } \\
\text { average }\end{array}$} \\
\hline & 5 & 10 & 15 & 20 & \\
\hline UFU-057F $\mathrm{RC}_{2} 10 \# 3.6 .1$ & 0.75 & 0.92 & 0.77 & 0.33 & $0.69 a$ \\
\hline UFU-057 $\mathrm{F}_{3} \mathrm{RC}_{2} 7 \# 4.3 .2$ & 1.53 & 1.62 & 1.52 & 0.83 & $1.38 b$ \\
\hline UFU-057F ${ }_{3} \mathrm{RC}_{2} 7 \# 4.7 .3$ & 1.73 & 1.70 & 0.53 & 0.77 & $1.18 b$ \\
\hline UFU-057F $\mathrm{RC}_{2} 8 \# 2.4 .1$ & 1.65 & 0.98 & 1.28 & 1.68 & $1.40 \mathrm{~b}$ \\
\hline UFU-057F $\mathrm{F}_{3} \mathrm{RC}_{2} 13 \# 4.4 .1$ & 0.88 & 1.22 & 0.62 & 1.47 & $1.05 b$ \\
\hline UFU-057F $\mathrm{F}_{3} \mathrm{RC}_{2} 7 \# 4.7 .1$ & 1.50 & 1.20 & 1.23 & 0.97 & $1.23 b$ \\
\hline UFU-057 ${ }_{3} \mathrm{RC}_{2} 7 \# 4.3 .2$ & 1.13 & 1.08 & 0.83 & 1.28 & $1.08 b$ \\
\hline UFU-057F $\mathrm{FC}_{3} 13 \# 2.1 .1$ & 1.07 & 1.83 & 1.03 & 1.12 & $1.26 b$ \\
\hline UFU-057F $\mathrm{RC}_{2} 13 \# 2.5 .2$ & 1.28 & 1.87 & 1.82 & 0.35 & $1.33 \mathrm{~b}$ \\
\hline UFU-057F $\mathrm{F}_{3} \mathrm{RC}_{2} 13 \# 2.5 .1$ & 1.37 & 1.23 & 0.93 & 1.13 & $1.17 \mathrm{~b}$ \\
\hline UFU-057F $\mathrm{F}_{3} \mathrm{RC}_{2} 13 \# 2.1 .2$ & 1.45 & 0.83 & 0.88 & 0.32 & $0.87 a$ \\
\hline UFU-057F $\mathrm{F}_{3} \mathrm{RC}_{2} 13 \# 2.1 .3$ & 1.80 & 1.57 & 0.43 & 0.92 & $1.18 b$ \\
\hline UFU-057 & 1.47 & 1.60 & 1.53 & 1.08 & $1.42 \mathrm{~b}$ \\
\hline Santa Clara & 2.70 & 1.95 & 1.05 & 2.03 & $1.93 \mathrm{~b}$ \\
\hline Rio Grande & 1.30 & 2.07 & 1.32 & 1.33 & $1.50 \mathrm{~b}$ \\
\hline Solanum pennellii & 0.00 & 0.22 & 0.07 & 0.00 & $0.07 \mathrm{a}$ \\
\hline Linear Regression & \multicolumn{4}{|c|}{ ns } & \\
\hline Ks & & & & & 0.01 \\
\hline $\mathrm{F}$ & & & & & 0.00 \\
\hline$F^{\prime}$ & & & & & 0.35 \\
\hline
\end{tabular}

${ }^{1}$ Means followed by the same letters in the column do not differ by the Scott-Knott test at $\mathrm{p} \leq 0.05$; ns - Not significant by F test; Ks, F, and F' - Assumptions of the KolmogorovSmirnov, Levene and Block additive tests, respectively; values in bold indicate residues without normal distribution, homogeneous variances and additive effects
The acylsugars, one of the substances which promotes plant resistance to insects, are associated with glandular trichomes, more precisely type IV (Maluf et al., 2010; Lucini et al., 2015). However, there are other resistance factors such as density and type of foliar trichomes, types of phytochemicals produced and cuticle thickness, which during plant selection, may not have been recovered (Maluf et al., 2010). Thus, it is normal for plants with high numbers of glandular trichomes to exhibit intermediate resistance to insects.

The genotypes UFU-057 $\mathrm{F}_{3} \mathrm{RC}_{2} 8 \# 2.4 .1$, UFU$057 \mathrm{~F}_{3} \mathrm{RC}_{2} 13 \# 4.4 .1$, UFU-057 $\mathrm{F}_{3} \mathrm{RC}_{2} 7 \# 4.7 .1$, UFU $057 \mathrm{~F}_{3} \mathrm{RC}_{2} 7 \# 4.3 .2$, UFU-057F ${ }_{3} \mathrm{RC}_{2} 13 \# 2.5 .2$, UFU $057 \mathrm{~F}_{3} \mathrm{RC}_{2} 13 \# 2.5 .1$, UFU $-057 \mathrm{~F}_{3} \mathrm{RC}_{2} 13 \# 2.1 .2$, UFU $057 \mathrm{~F}_{3} \mathrm{RC}_{2} 13 \# 2.1 .3$ and UFU-057 showed productivity similar to the commercial cultivars Santa Clara and Rio Grande. These same genotypes, with the exception of UFU-057 $\mathrm{F}_{3} \mathrm{RC}_{2} 8 \# 2.4$.1, UFU-057F $\mathrm{RC}_{2}$ 13\#2.5.1 and UFU-057 also presented numbers of fruits per plant that were similar to the commercial cultivars Santa Clara and Rio Grande (Table 1). This probably occurred due to the higher acylsugar levels present in these accessions and consequent greater resistance to pest attack.

The genotype UFU-057F $\mathrm{RC}_{2} 8 \# 2.4$.1 presented fruits of greater mass (81.86 g), while UFU-057 (recurrent parent) and UFU-057F $\mathrm{RC}_{2} 13 \# 2.5 .2$ were intermediate in fruit mass with values of 65.63 and $59.14 \mathrm{~g}$, respectively. These genotypes were superior to the commercial cultivars Santa Clara and Rio Grande. The increases in fruit mass compared to fruits produced by the Santa Clara cultivar were $62.71 \%$ for UFU$057 \mathrm{~F}_{3} \mathrm{RC}_{2} 8 \# 2.4 .1,30.45 \%$ for UFU-057 and $17.55 \%$ for UFU$057 \mathrm{~F}_{3} \mathrm{RC}_{2} 13 \# 2.5 .2$. Relative to the Rio Grande cultivar, the increase in fruit mass was $74.77 \%$ in UFU-057 $\mathrm{F}_{3} \mathrm{RC}_{2} 8 \# 2.4 .1$, $40.12 \%$ in UFU-057 and $26.26 \%$ in UFU-057F $\mathrm{RC}_{2} 13 \# 2.5 .2$ (Table 1).

The average fruit mass may be influenced by environmental factors, genotypes, number of stems per plant, number of fruits per plant, planting density and number of seeds per fruit (Peil et al., 2014; Peixoto et al., 2018). In the present study, an inverse relationship between the number of fruits per plant and the average fruit mass was confirmed. The genotypes that presented the greatest number of fruits per plant produced fruits with lower average mass. For this variable, the data of the S. pennellii access were not considered as it does not produce fruits with characteristics desirable for commercialization (Table 1).

The genotypes that present fruits with SS levels above $3{ }^{\circ} \mathrm{Brix}$ may have their production directed to fruit markets in natura (Schwarz et al., 2013). On the other hand, fruits destined for industrial processing must have a minimum of $5{ }^{\circ} \mathrm{Brix}$ (Cemeroglu et al., 2003). All genotypes characterized in this work can have their fruits commercialized for the fruit market in natura. Approximately $81 \%$ of the genotypes analysed in the present study had SS concentrations higher than $5{ }^{\circ}$ Brix and thus made it possible to use them in the industry (Table 1).

SS concentrations are directly related to industrial yield. Each ${ }^{\circ}$ Brix increase in the raw material makes it possible to increase the average pulp yield by approximately 10 to $20 \%$ (Clemente \& Boitex, 2012). The highest SS concentrations were obtained in the fruits of $S$. pennellii $\left(7.57^{\circ} \mathrm{Brix}\right)$. This 
shows that interspecific crossing using $S$. pennellii adds even more to this property. Of the genotypes that present fruits with desirable commercialization characteristics, the highest SS value was observed in UFU-057F $\mathrm{RC}_{2} 7 \# 4.3 .2$ (6.73 $\left.{ }^{\circ} \mathrm{Brix}\right)$ (Table 1).

The highest TTA values were found in fruits produced by wild access $S$. pennellii (1.31\%) and genotype UFU$057 \mathrm{~F}_{3} \mathrm{RC}_{2} 7 \# 4.3 .2(0.99 \%)$. These genotypes consequently presented fruits with the highest ACAs of 0.84 and $0.63 \%$, respectively (Table 1 ). These results were expected since the predominant acid in tomato fruits is citric acid (Anthon \& Barrett, 2012). The acidity present in tomato fruits influences the taste and final product.

Fruit acidity influences industrial processing by reducing the time necessary for sterilizing the product (Soares \& Rangel, 2012) which therefore reduces costs for the industry. Tomato fruits with citric acid concentrations below $0.35 \%$ require both time and temperature increases for controlling microorganisms in processed products (Clemente \& Boiteux, 2012).

The genotypes did not differ in their SS/TTA ratios. All genotypes showed $\mathrm{pH}$ values within the ideal range (below 4.6) (Table 1). For this reason, tomato fruits are considered an acidic food (Anthon \& Barrett, 2012).

There were no interactions between genotypes and the distance covered by Tetranychus urticae. However, the genotypes differed from each other. UFU-057F $\mathrm{RC}_{2} 10 \# 3.6 .1$ $(0.69 \mathrm{~cm})$ and UFU-057F $\mathrm{RC}_{2} 13 \# 2.1 .2(0.87 \mathrm{~cm})$ were similar to $S$. pennellii $(0.07 \mathrm{~cm})$ and presented the lowest values for distance covered by two-spotted spider mites (Table 2). This suggests that such accesses may be promising candidates for breeding programmes aiming at resistance to this mite.

In several studies evaluating tomato resistance to Tetranychus urticae, Bemisia tabaci, Liriomyza spp. and Tuta absoluta, among other insects, the authors observed an association between higher acylsugar concentrations and increased plant resistance (Lucini et al., 2015; Rakha et al., 2017; Maciel et al., 2018a; Peixoto et al., 2019). These data corroborate with those found in the present study.

The cophenetic correlation coefficient (CCC) value observed in this study was $95.94 \%$, with $4.77 \%$ distortion and shows an adequate relationship between the distance matrix and the generated dendrogram (Figure 1).

The groups were distinguished by the cut line considering $13 \%$ dissimilarity among genotypes. Formation of five groups was observed. Group I consisted of $68.75 \%$ of the genotypes. Group II consisted of access UFU-057 $\mathrm{F}_{3} \mathrm{RC}_{2} 7 \# 4.3 .2$. Group III consisted of UFU-057 $\mathrm{F}_{3} \mathrm{RC}_{2} 8 \# 2.4 .1$ and the recurrent parent UFU-057. Groups IV and V each consisted of only one genotype, namely, Santa Clara and Solanum pennellii, respectively.

For an adequate interpretation of the variability among genotypes, it is necessary that the first canonical variables allow an estimate of more than $80 \%$ of all of the variability contained in the character set (Cruz et al., 2014). In the present study, the first three canonical variables explained $90.98 \%$ of the variation among genotypes (Figure 2).

It is possible to observe in the dispersion graph (Figure 2) the formation of the same five groups which are seen in the dendrogram (Figure 1). This similarity between the methods allows greater confidence in the selection of potential parents in programmes for improving salad-type tomato with a

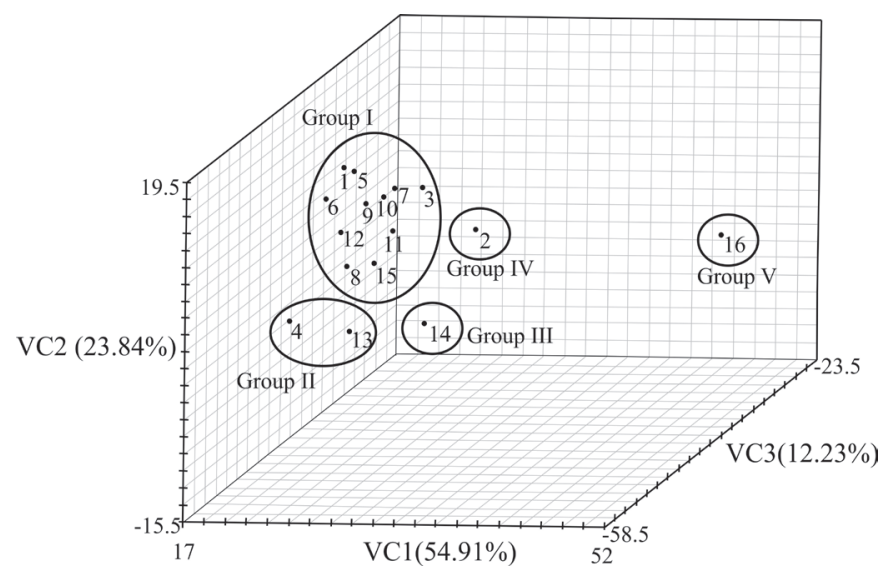

1 - UFU-057F $\mathrm{RC}_{2} 10 \# 3.6 .1,2$ - UFU-057F $\mathrm{RC}_{2} 7 \# 4.3 .2,3$ - UFU-057F $\mathrm{RC}_{2} 7 \# 4.7 .3$, 4 - UFU-057F $\mathrm{RC}_{2} 8 \# 2.4 .1,5$ - UFU-057F $\mathrm{RC}_{2} 13 \# 4.4 .1,6$ - UFU-057F $\mathrm{RC}_{2} 7 \# 4.7 .1$, 7 - UFU-057F RC 7\#4.3.2, 8 - UFU-057F RC 13\#2.1.1, 9 - UFU-057F RC 13\#2.5.2, 10 - UFU-057F $\mathrm{RC}_{2} 13 \# 2.5 .1,11$ - UFU-057F $\mathrm{RC}_{2} 13 \# 2.1 .2,12$ - UFU-057F $\mathrm{RC}_{2} 13 \# 2.1 .3$, 13 - UFU-057, 14 - Santa Clara, 15 - Rio Grande, and 16 - Solanum pennellii

Figure 2. Dispersion graph of 16 tomato genotypes in relation to the scores of the first three canonical variables, $\mathrm{VC} 1$ (54.91\%), VC2 (23.84\%) and VC3 (12.23\%)

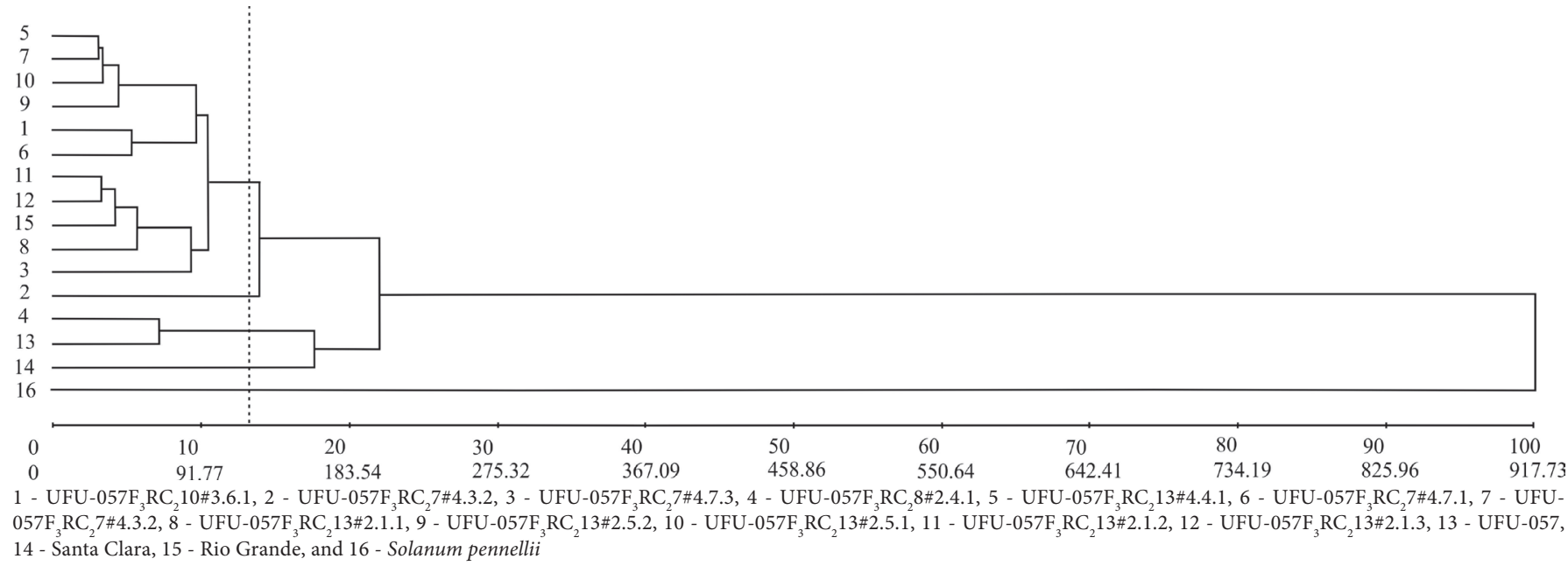

Figure 1. Illustrative dendrogram analysis of 16 tomato genotypes using the unweighted pair-group method with arithmetic mean (UPGMA) obtained with the Mahalanobis distance generated with 12 characters 
Table 3. Grouping of tomato genotypes by Tocher's optimization method, as estimated with the Mahalanobis generalized distance

\begin{tabular}{|c|c|}
\hline Group & Genotypes \\
\hline I & 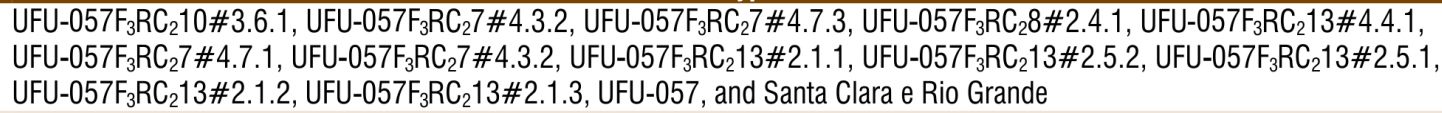 \\
\hline II & Solanum pennellii \\
\hline
\end{tabular}

determinate growth habit and aiming at resistance to the twospotted spider mite.

The formation of two groups was observed in the Tocher optimization method. The first group consisted of $93.75 \%$ of the analysed genotypes. The second group was formed only by wild access (Table 3 ). This shows the low discrimination power of the genetic diversity between the genotypes analysed by this method. Therefore, it is important that the breeder compare different methods of multivariate analysis in search of genetic diversity among genotypes (Cruz et al., 2014).

The variables with the greatest contributions to genetic diversity among the genotypes were the number of trichomes on the adaxial side of the leaf (32.32\%), acylsugar concentrations (16.96\%), average fruit mass $(15.32 \%)$ and soluble solids concentrations (11.83\%) (Table 4$)$.

The uni- and multivariate analyses have different calculation methodologies (Araujo et al., 2016). However, both are complementary for determining the variability among tomato genotypes and aid the decisions of the breeder.

Table 4. Relative contributions (\%) of characteristics for genetic divergence in salad-type tomato genotypes, as estimated by the method proposed by Singh (1981)

\begin{tabular}{|c|c|}
\hline Variable & $\begin{array}{l}\text { S.j } \\
(\%)\end{array}$ \\
\hline Number of trichomes on the adaxial face of the leaf & 32.32 \\
\hline Concentration of acylsugar $\left(\mathrm{nmol} \mathrm{cm}{ }^{-2}\right)$ & 16.96 \\
\hline Average fruit mass (g) & 15.32 \\
\hline Soluble solids concentration ( ${ }^{\circ}$ Brix) & 11.83 \\
\hline Acidity of citric acid (\%) & 6.52 \\
\hline Productivity of fruits (kg per plant) & 6.48 \\
\hline Titratable total acidity (\%) & 5.22 \\
\hline $\mathrm{pH}$ & 2.38 \\
\hline Number of trichomes on the abaxial face of the leaf & 0.90 \\
\hline Number of fruits per plant & 0.80 \\
\hline Distance travelled by the mite Tetranychus urticae & 0.72 \\
\hline $\begin{array}{l}\text { Ratio between the soluble solids concentration and the } \\
\text { titratable total acidity }\end{array}$ & 0.53 \\
\hline
\end{tabular}

S.j - Percentages of the relative contribution of the evaluated characteristics to diversity according to the measure of the relative importance of variable $j$

\section{Conclusions}

1. The genotypes UFU-13\#4.4.1, UFU-7\#4.7.1, UFU7\#4.3.2, UFU-13\#2.5.2 and UFU-13\#2.1.3 presented higher sugar concentrations than Solanum pennellii, higher productivity and number of fruits per plant.

2. It is suggested that combinations be made between genotypes UFU-13\#4.4.1, UFU-7\#4.7.1, UFU-7\#4.3.2, UFU13\#2.5.2 and UFU-13\#2.1.3 with UFU-8\#2.4.1 to obtain hybrids with high acylsugar, resistance to the two-spotted spider mite, high productivity and increased fruit mass.

3. Genotypes UFU-057 $\mathrm{F}_{3} \mathrm{RC}_{2} 10 \# 3.6 .1$ and UFU$057 \mathrm{~F}_{3} \mathrm{RC}_{2} 13 \# 2.1 .2$ are promising candidates for genetic improvement for resistance to the two-spotted spider mite.

\section{ACKNowledgements}

The authors are grateful to Coordenação de Aperfeiçoamento de Pessoal de Nível Superior (CAPES), Fundação de Amparo à Pesquisa do Estado de Minas Gerais (FAPEMIG), Conselho Nacional de Desenvolvimento Científico e Tecnológico (CNPq) and Universidade Federal de Uberlândia (UFU) for their financial support, fellowships and infrastructure.

\section{Literature Cited}

Alvarenga, M. A. R. Tomate: Produção em campo, casa de vegetação e hidroponia. 2.ed. Lavras: UFLA, 2013. 455p.

Alyokhin, A.; Mota-Sanchez, D.; Baker, M.; Snyder, W. E.; Menasha, S.; Whalon, M.; Dively, G.; Moarsi, W. F. The Red Queen in a potato field: Integrated pest management versus chemical dependency in Colorado potato beetle control. Pest Management Science, v.71, p.343-356, 2015. https://doi.org/10.1002/ps.3826

Anthon, G. E.; Barrett, D. M. Pectin methylesterase activity and other factors affecting $\mathrm{pH}$ and titratable acidity in processing tomatoes. Food Chemistry, v.132, p.915-920, 2012. https://doi.org/10.1016/j. foodchem.2011.11.066

AOAC - Association of Official Analytical Chemists. Official methods of analysis of Association of Official Analytical Chemists. 20.ed. Gaithersburg: AOAC International, 2016. 3172p.

Araujo, J. C.; Telhado, S. F. P.; Sakai, R. H.; Ledo, C. A. S.; Melo, P. C. T. Univariate and multivariate procedures for agronomic evaluation of organically grown tomato cultivars. Horticultura Brasileira, v.34, p.374-380, 2016. https://doi.org/10.1590/S0102-05362016003011

Cemeroglu, B.; Karadeniz, F.; Ozkan, M. Meyve sebze isleme teknolojisi. Gıda Teknolojisi Yayınları, v.28, p.469-472, 2003.

Clemente, F. M. V. T.; Boiteux, L. S. Produção de tomate para processamento industrial. 1.ed. Brasília: Embrapa Hortaliças, 2012. 344p.

Cruz, C. D. GENES: A software package for analysis in experimental statistics and quantitative genetics. Acta Scientiarum. Agronomy, v.35, p.271-276, 2013.

Cruz, C. D.; Carneiro, P. C. S.; Regazzi, A. J. Modelos biométricos aplicados ao melhoramento genético. 3.ed. Viçosa: UFV, 2014. $668 \mathrm{p}$.

Glas, J. J.; Schimmel, B. C. J.; Alba, J. M.; Escobar-Bravo, R.; Schuurink, R. C.; Kant, M. R. Plant glandular trichomes as targets for breeding or engineering of resistance to herbivores. International Journal of Molecular Sciences, v.13, p.17077-17103, 2012. https://doi. org/10.3390/ijms131217077

Gruber, K. The living library: Wild and heirloom plants are giving major crop varieties, and the global food system, a genetic makeover. Nature, v.544, p.8-10, 2017. https://doi. org/10.1038/544S8a

IBM SPSS - Statistical Package for the Social Sciences. Statistics versão 25.0.0.0. IBM Software. Armonk: IBM Corp, 2019. Available in: $<$ https://spss.pt.downloadastro.com/>. Accessed on: Fev. 2019. 
Lucini, T.; Faria, M. V.; Rohde, C.; Resende, J. T. V. de; Oliveira, J. R. F. de Acylsugar and the role of trichomes in tomato genotypes resistance. Arthropod-Plant Interactions, v.9, p.45-53, 2015. https://doi.org/10.1007/s11829-014-9347-7

Luu, V. T.; Weinhold, A.; Ullah, C.; Dressel, S.; Schoettner, M.; Gase, K.; Gaquerel, E.; Xu, S.; Baldwuin, I. T. O-acyl sugars protect a wild tobacco from both native fungal pathogens and a specialist herbivore. Plant Physiology, v.174, p.370-386, 2017. https://doi. org/10.1104/pp.16.01904

Maciel, G. M.; Marquez, G. R.; Silva, E. C. da; Andaló, V.; Belloti, I. F. Tomato genotypes with determinate growth and high acylsugar concentration presenting resistance to spider mite. Crop Breeding and Applied Biotechnology, v.18, p.1-8, 2018a. https://doi. org/10.1590/1984-70332018v18n1a1

Maciel, G. M.; Peixoto, J. V. M.; Rocha, J. P. R.; Almeida, R. S.; Oliveira, C. S.; Mendonça, T. F. N. Multivariate techniques in the determination of genetic diversity in pest-resistant mini tomato genotypes. Horticultura Brasileira, v.36, p.504-509, 2018b. https:// doi.org/10.1590/s0102-053620180413

Maciel, G. M.; Silva, E. C. Proposta metodológica para quantificação de acilaçúcares em folíolos de tomateiro. Horticultura Brasileira, v.32, p.174-177, 2014. https://doi.org/10.1590/S010205362014000200009

Maluf, W. R.; Maciel, G. M.; Gomes, L. A. A.; Cardoso, M. G.; Gonçalves, L. D.; Silva, E. C. da; Knapp, M. Broad-spectrum arthropod resistance in hybrids between high and low-acylsugar tomato lines. Crop Science, v.50, p.439-450, 2010. https://doi. org/10.2135/cropsci2009.01.0045

Mantel, N. The detection of disease clustering and a generalized regression approach. Cancer Research, v.27, p.209-220, 1967.

Peil, R. M. N.; Albuquerque Neto, A. A. R.; Rombaldi, C. V. Densidade de plantio e genótipos de tomateiro cereja em sistema fechado de cultivoem substrato. Horticultura Brasileira, v.32, p.234-240, 2014. https://doi.org/10.1590/S0102-05362014000200021

Peixoto, J. V. M.; Almeida, R. S. de; Rocha, J. P. R. da; Maciel, G. M.; Santos, N. C.; Pereira, L. M. Hierarchical and optimization methods for the characterization of tomato genotypes. Revista Brasileira de Engenharia Agrícola e Ambiental, v.23, p.27-32, 2019. https://doi.org/10.1590/1807-1929/agriambi.v23n1p27-32
Peixoto, J. V. M.; Garcia, L. G. C.; Nascimento, A. dos R.; Moraes, E. R. de; Ferreira, T. A. P. de C.; Fernandes, M. R.; Pereira, V. de A. Post-harvest evaluation of tomato genotypes with dual purpose. Food Science and Technology, v.38, p.1-8, 2018. https://doi. org/10.1590/1678-457x.00217

Rakha, M.; Bouba, N.; Ramasamy, S.; Regnard, J.-L.; Hanson, P. Evaluation of wild tomato accessions (Solanum spp.) for resistance to two-spotted spider mite Tetranychus urticae Koch) based on trichome type and acylsugar concentration. Genetic Resources and Crop Evolution, v.64, p.1011-1022, 2017. https:// doi.org/10.1007/s10722-016-0421-0

Resende, J. T. V.; Cardoso, M. G.; Maluf, W. R.; Santos, C. D.; Gonçalves, L. D.; Resende, L. V.; Naves, F. O. Método colorimétrico para quantificação de acilaçúcar em genótipos de tomateiro. Ciência e Agrotecnologia, v.26, p.1204-1208, 2002.

Resende, M. D. V. Genética quantitativa e de populações. 1.ed. Viçosa: Produção Independente, 2015. 463p.

Schwarz, K.; Resende, J. T. V. de; Preczenhak, A. P.; Paula, J. T. de; Faria, M. V.; Dias, D. M. Desempenho agronômico e qualidade físicoquímica de híbridos de tomateiro em cultivo rasteiro. Horticultura Brasileira, v.31, p.410-418, 2013. https://doi.org/10.1590/S010205362013000300011

Singh, D. The relative importance of characters affecting genetic divergence. The Indian Journal of Genetic and Plant Breeding, v.41, p.237-245, 1981.

Soares, B. B.; Rangel, R. Aspectos industriais da cultura. In: Clemente, F. M. V. T.; Boiteux, L. S. Produção de tomate para processamento industrial. Brasília: Embrapa Hortaliças, 2012. Cap.15, p.331-344.

Vosman, B.; Westende, W. P. C. van't; Henken, B.; Eekelen, H. D. L. M. van; Vos, R. C. H.; Voorrips, R. E. Broad spectrum insect resistance and metabolites in close relatives of the cultivated tomato. Euphytica, v.214, p.1-14, 2018. https://doi.org/10.1007/ s10681-018-2124-4

Weston, P. A.; Snyder, J. C. Thumbtack biossay: A quick method of measuring plant resistence to twospotted spider mites (Acari: Tetranychidae). Journal of Economic Entomology, v.83, p.501504, 1990. https://doi.org/10.1093/jee/83.2.500 